\title{
A case of scoliosis and mental retardation presenting with spontaneous pneumothorax
}

\author{
Spontan pnömotoraks ile başvuran skolyoz ve mental retardasyon olgusu \\ Yücel Akkaş*, Özgür Katrancıŏ̆lu \\ Thoracic Surgery (Y. Akkaş, MD, Ö. Katrancıŏglu, MD), Sivas Numune Hospital, TR-58040 \\ Sivas
}

\begin{abstract}
Scoliosis is generally defined as the curvature of the spine laterally on the frontal plane. Primary spontaneous pneumothorax is generally seen in young men who are in second and third decades, after rupture of subpleural bleb. We reported a patient who had a scoliosis and mental retardation with spontaneous pneumothorax. Thirty-one years old male patient who had a mental retardation and severe scoliosis was admitted to the emergency service with complaint of shortness of breath. The patient's physical examination revealed no breath sounds on the right side. Total pneumothorax was seen on the right hemithorax and the convex part of the scoliosis was seen pointing to the right on posteroanterior (PA) chest radiography and computed tomography (CT) imaging of the thorax. The right tube thoracostomy was performed under anesthesia. Patient, who can not do adequate breathing exercise because of mental retardation, was treated with Gomco. When air leak from the chest tube stopped and PA chest radiography was expanse on the seventh day, it was pulled out and the patient was externed. Six months later recurrence was not observed. Spontaneous pneumothorax in patients with severe scoliosis that can lead to the development of cardiopulmonary disorders can be a life-threatening situation and urgent correction of this type of pneumothorax in patients can be life-saving.
\end{abstract}

Keyword: Scoliosis, spontaneous pneumothorax, mental retardation

\section{Özet}

Skolyoz genel olarak omurganın frontal düzlemde laterale doğru eğriliği olarak tanımlanmaktadır. Primer spontan pnömotoraks daha çok genç erkeklerde 2.-3. dekatlarda subplevral bleplerin rüptürü sonucu görülmektedir. Biz mental retarde skolyozu olan bir hastada pnömotoraks birlikteliğini bildirdik. Otuzbir yaşında mental retarde ve ağır skolyozlu erkek hasta nefes darlığı şikayeti ile acil servise başvurdu. Hastanın fizik muayenesinde dinlemekle sağda solunum sesleri alınmıyordu. Posteroanterior (PA) akciğer grafisi ve bilgisayarlı toraks tomografisi (BT) görüntülemesinde sağda total pnömotoraks ve konveks kısmı sağa bakan skolyoz görülmekteydi. Hastaya anestezi altında sağ tüp torakostomi yapıldı. Mental retarde olan hasta tüp torakostomi sonrası yeterli solunum egzersizi yapamadığı için, gomco tedavisi yapıldı. Hastanın göğüs tüpünden hava kaçağının kesilmesi ve PA akciğer grafisinin ekspanse olması üzerine 7. gün göğüs tüpü çekilerek taburcu edildi. Altı ay sonra nüks görülmedi. Kardiyopulmoner bozukluklara yol açabilen ağır skolyozlu hastalarda spontan pnömotoraks gelişmesi hayatı tehdit edici bir durum olabilir ve acil olarak bu tip hastalarda pnömotoraksın düzeltilmesi yaşam kurtarıcıdır.

Anahtar sözcükler: Skolyoz, spontan pnömotoraks, mental retardasyon

Geliş tarihi/Received: July 14, 2011; Kabul tarihi/Accepted: December 22, 2011

\section{Corresponding author:}

Dr. Yücel Akkaş, Göğüs Cerrahisi, Sivas Numune Hastanesi, TR-58040 Sivas. E-mail: y.akkas@yahoo.com 


\section{Introduction}

Scoliosis is generally defined as the curvature of the spine laterally on the frontal plane $[1,2]$. Scoliosis can lead to right-sided heart failure as a result of recurrent lung infections, hypoxia, increasing the pulmonary resistance and pulmonary hypertension in advanced stages $[1,2]$. Primary spontaneous pneumothorax in young man who are in second and third decades, is seen as a result of rupture of subpleural bleb [3]. We reported a patient who had a scoliosis and mental retardation with spontaneous pneumothorax, due to the rare observation in literature and creating a severe clinical picture.

\section{Case report}

Thirty-one years old male patient who had a mental retardation and severe scoliosis was admitted to the emergency service with complaint of shortness of breath. The patient's physical examination, listening to breath sounds not being heard on the right side. Posteroanterior chest radiography and computed tomography imaging of the thorax total pneumothorax was seen on the right hemithorax and the convex part of the scoliosis was seen pointing to the right (Figure 1 and 2). The right tube thoracostomy was performed under anesthesia. Patient who can't do adequate breathing exercise because of mental retardation, was treated with Gomco. When air leak was stopped from the chest tube on the seventh day, it was pulled out (Figure 3). Six months later recurrence was not observed.

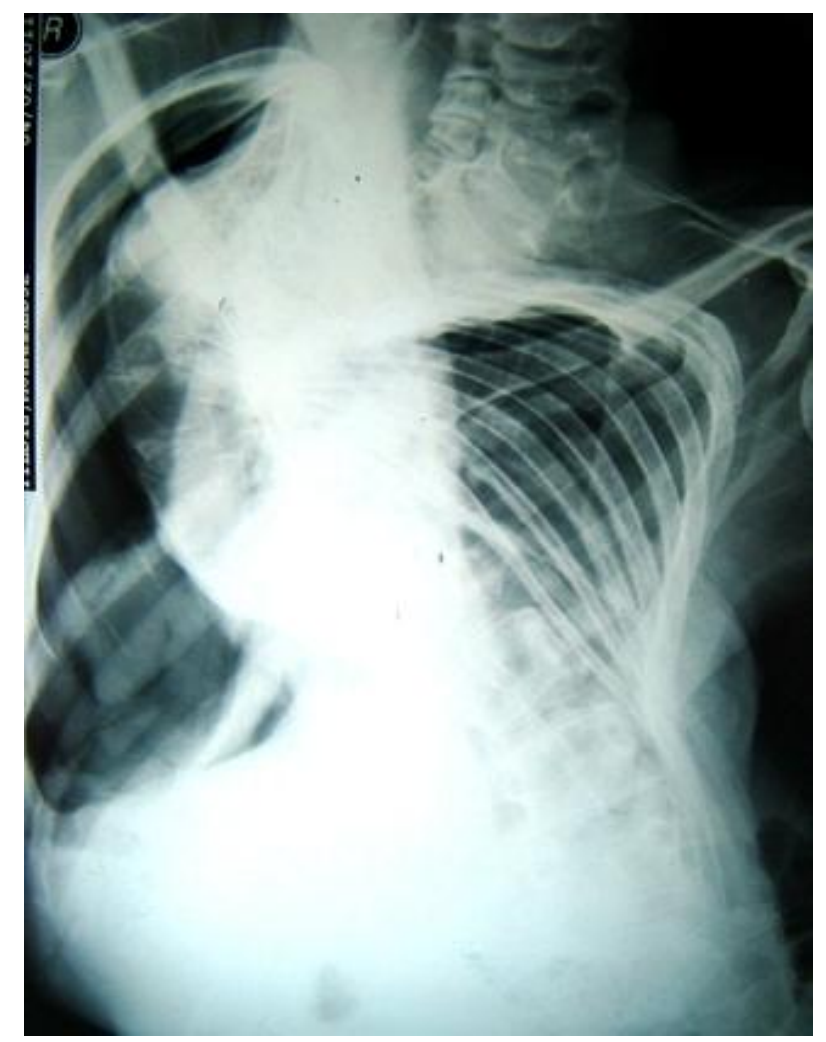

Figure1. PA chest radiography is shown that total pneumothorax on the right hemithorax and convex part of the scoliosis pointing to the right. 


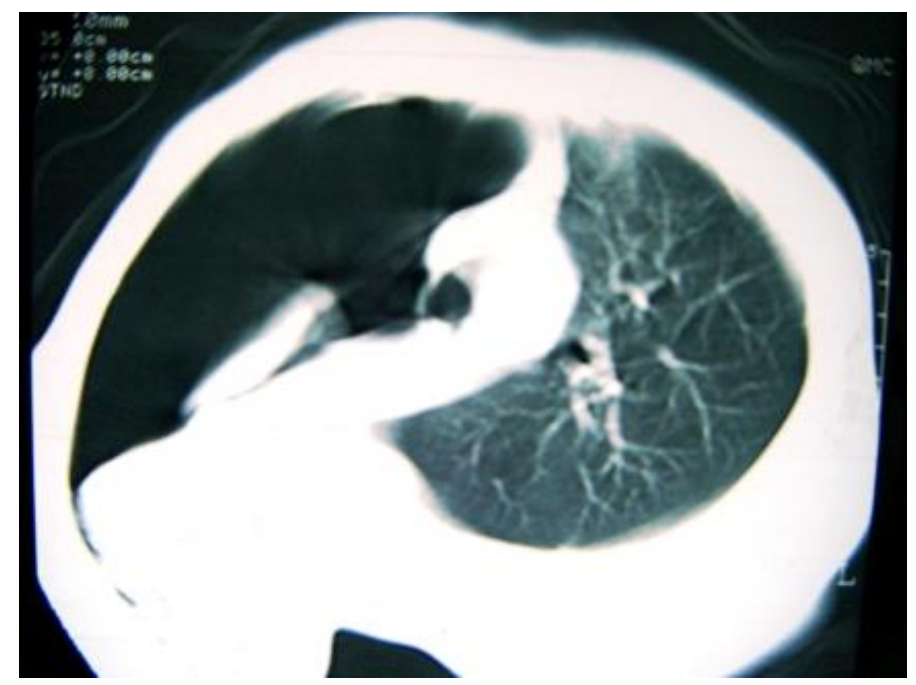

Figure2. Thorax CT revealed total pneumothorax on the right hemithorax.

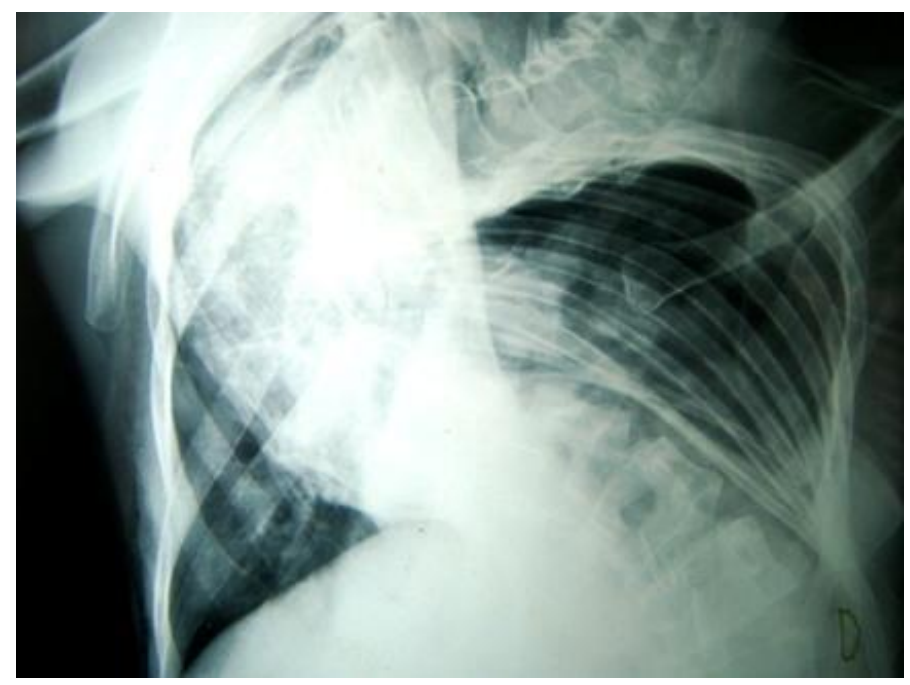

Figure3. PA chest radiography showed improved image of pneumothorax after chest tube.

\section{Discussion}

Severe scoliosis usually leads to respiratory problems in the second decade and in third decade leads to increase the chronic respiratory failure [1, 4]. Early detection of scoliosis and taking necessary medical precautions is necessary in prevention of progression in most patients. There are various factors affecting prognosis in scoliosis such as age, sex, type of curvature, and size [1]. Treatment of scoliosis is conservative or surgical. The goal is to prevent progression and correction of the curvature [1].

Early diagnosis of scoliosis increases the possibility of treatment enabling the patient to rid of the complications like pneumothorax and hemothorax likely to occur in the future with least damage [1]. As a result, we believe that diagnosing scoliosis in an early period school screening should be given more importance.

Severe scoliosis in patients with already impaired pulmonary function cause more severe clinical picture with pneumothorax. In our patient, severe scoliosis caused a worsened clinical picture. In addition to all this, the patient is mentally retarded and made it difficult to express himself because of that tube thoracostomy was 
performed under anesthesia. Because of the pneumothorax which was developed at the convex side of scoliosis that made it easier for us to perform tube thoracostomy. If the pneumothorax was occurred at the concav side of the scoliosis, we believe that the process would be more difficult. After the process another problem of the patient was not to have adequate breathing exercises. To this, Gomco was applied to this patient for expansion of the lung.

In the literature early diagnosis and treatment are reported that is to be life-saving when the pneumothorax is developed in patients with severe scoliosis [5, 6]. In our patient, the early diagnosis and treatment has saved our patient's life. We believe in the necessity of early diagnosis and treatment in these patients.

Spontaneous pneumothorax in patients with severe scoliosis that can lead to the development of cardiopulmonary disorders can be a life-threatening situation and urgent correction of this type of pneumothorax in patients can be life-saving.

\section{References}

1. Adak B, Onen M.S, Tekeoglu I, Arslan A. Van ili merkez ilköğretim okullarında skolyoz taramas1. Fiziksel T1p ve Rehabilitasyon Dergisi 1999; 2: 22-32.

2. Öner C, Yenerkol B, Batmaz F. Eskişehir Merkez İlkokullarında Skolyoz Taraması Ege Tıp Rehabilitasyon Dergisi, Eskişehir 1997; 203-7.

3. Sahin E, Kaptanoglu M, Nadir A, Akkas Y. Spontan pnömotorakslarda tedavi yaklaşımları: 14 yıllık deneyimimiz. Akciğer Arşivi, 2007; 8: 19-22.

4. Woolf CR. Kyphoscoliosis and respiratory failure. A patient treated with assisted ventilation for 27 years. Chest 1990; 98: 1297-8.

5. Sucato DJ, Girgis M. Bilateral pneumothoraces, pneumomediastinum, pneumoperitoneum, pneumoretroperitoneum, and subcutaneous emphysema following intubation with a double-lumen endotracheal tube for thoracoscopic anterior spinal release and fusion in a patient with idiopathic scoliosis. J Spinal Disord Tech 2002; 15: 133-8.

6. Roush TF, Crawford AH, Berlin RE, Wolf RK. Tension pneumothorax as a complication of video-assisted thorascopic surgery for anterior correction of idiopathic scoliosis in an adolescent female. Spine (Phila Pa 1976) 2001; 26: 44850 . 